\title{
Strategi Pengembangan Bisnis Wisata Syariah Pada Masyarakat Pluralis di Kabupaten Ponorogo
}

\author{
Ika Susilawati \\ Fakultas Ekonomi dan Bisnis Islam, IAIN Ponorogo, Jawa Timur, Indonesia \\ Email: ika.susilawati79@gmail.com
}

\begin{abstract}
The development of sharia tourism has a multidimensional impact. One of them is employment and poverty alleviation, especially in Ponorogo, considering that is the 11th largest city contributing to Indonesian migrant workers. The development of the sharia tourism business is increasingly attractive, because the Ponorogo community is a pluralistic society, which embraces a variety of cultures, religions and creeds. So that the role of local government as a leading sector is needed to determine the planning and development of regional sharia tourism. For that we need the right strategy in the development of Islamic tourism in accordance with the characteristics of Ponorogo. In the formulation of the right strategy, data from Muslim, non-Muslim and local government communities is needed. The data is analyzed by the SWOT technique which is supported by internal and external factors. With the result has the potential in the development of sharia tourism considering there are still many natural tourism objects that have not been touched and developed by the community or local government. The development of Islamic tourism is approved by Muslim, non-Muslim communities, while maintaining their respective religious sites. The strategy generated from the SWOT analysis formed a map diagram of the development of sharia tourism business in Ponorogo.
\end{abstract}

Keywords: American Islam, Individualization of Religion, Sufism, Islamic Mysticism.

\begin{abstract}
Abstrak
Perkembangan wisata syariah memberikan dampak multidimensi. Salah satunya adalah penyerapan tenaga kerja dan pengentasan kemiskinan, terutama di ponorogo, mengingat ponorogo merupakan kota urutan ke 11 menyumbang TKI terbesar di Indonesia. Pengembangan bisnis wisata syariah di ponorogo ini semakin manarik, karena masyarakat ponorogo merupakan masyarakat yang pluralism, yang menganut berbagai macam budaya, agama dan aliran kepercayaan. Sehingga diperlukan peran dari pemerintah daerah sebagai leading sector menentukan perencanaan dan pembangunan wisata syariah daerah. Untuk itu di perlukan strategi yang tepat dalam pengembangan wisata syariah yang sesuai dengan karakteristik ponorogo. Dalam
\end{abstract}


perumusan strategi yang tepat, di perlukan data dari masyarakat muslim, non muslim dan pemerintah daerah. Data tersebut di analisis dengan teknik SWOT yang di dukung dengan teknik internal dan eksternal faktor. Dengan hasil bahwa ponorogo berpotensi dalam pengembangan wisata syariah mengingat masih banyak obyek wisata alam yang belum tersentuh dan belum di kembangkan oleh masyarakat maupun pemerintah daerah. Pengembangan wisata syariah ini di setujui oleh masyarakat muslim maupun non muslim, dengan tetap mempertahankan situs agama masing-masing. Dalam pengembangannya diperlukan adanya sinergi terutama dari para pemegang saham untuk pembiayaannya. Strategi yang di hasilkan dari analisis SWOT membentuk diagram peta pengembangan bisnis wisata syari' ah di ponorogo.

Kata Kunci: American Islam, Individualization of Religion, Sufism, Islamic Mysticism.

\section{Pendahuluan}

Industri keuangan syariah Indonesia mengalami pertumbuhan yang cukup signifikan. Hal ini di tunjukkan dengan jumlah asset keuangan syariah Indonesia dari September 2018 sejumlah sekitar Rp.1.265,97 triliun menjadi sekitar Rp. $1.291,48$ trilliun rupiah pada bulan Januari 2019, sehingga terjadi peningkatan sebesar Rp. 25,5 triliun, yang di dominasi oleh Sukuk Negara sebesar Rp. 651,29 triliun (50,4\%), posisi kedua Perbankan syari'ah sebesar RP.479,17 triliun (37,1\%), posisi ketiga asset Asuransi syariah mencapai Rp.43,12 triliun (3,34\%), posisi keempat Reksadana syari'ah Rp.37,3 triliun (2,89\%), disusul asset Lembaga nonbank syariah Rp.32,43 triliun (2,5\%), Pembiayaan syariah Rp.25,61 triliun (1,99\%), Sukuk korporasi Rp.22,56 triliun (1,78\%) (OJK, Aset Industri Keuangan Syariah di Indonesia, Mei 2019). Selain ketiga sektor keuangan tersebut, keberadaan dana sosial juga memiliki peran yang penting dalam perekonomian dan pembangunan di Indonesia, misalkan dana haji di perkirakan memiliki asset lebih dari 93 trilliun rupiah, sementara zakat tahun 2017 sekitar 6,22 trilliun rupiah. Sedangkan asset wakaf yang tercatat di kementerian agama seluas 435 juta meterpersegi dan tersebar di 274.061 lokasi mencapai 199 miliar rupiah di tahun 2017 (BAPPENNAS, 2018) . Kendati pengalami pertumbuhan setiap tahun, namun secara keseluruhan dampak dari industri keuangan syariah terhadap ekonomi nasional relative sangat kecil jika di bandingkan dengan ekonomi konvensional. Misalkan perbankkan syari'ah baru menguasai pangsa pasar perbankkan nasional sekitar 5,3 persen, begitu juga dengan sector keuangan lain, seperti pasar modal syari' ah, asuransi syari ah dan industri keuangan non bank juga baru penguasai 5 persen pangsa pasarnya.

Blue Print "Ekonomi dan Keuangan Syariah" yang dikeluarkan Bank Indonesia, menyebutkan bahwa aspek utama yang menjadi kekuatan sektor ekonomi islam di Indonesia adalah besarnya pasar domestik industry halal di Indonesia, karena, indonesia merupakan negara dengan penduduk muslim 
terbesar di dunia yaitu mencapai 230 juta orang atau 87,2 persen dari total penduduk di Indonesia (Nations, World Populations Prospects, 2017). Berdasarkan kekuatan yang ada di Indonesia, maka yang bisa di lakukan adalah mengoptimalisasi pemberdayaan secara total pada sector riil (industry halal). Saat ini, variasi usaha halal masih sangat terbatas dan terkonsentrasi pada sector tertentu, seperti makanan dan konsmetik halal. Padahal usaha lain seperti busana muslim syariah, obat-obatan halal dan pariwisata syariah juga berpotensi untuk di kembangkan.

Pilgrims tourism/spiritual tourism menjadi pondasi pengembangan rencana wisata syariah. Sekarang ini, wisata syariah tidak terbatas dalam jenis wisata religi, tetapi terjadi pengembangan nilai yang bersifat universal seperti kearifan lokal, memberi manfaat bagi masyarakat dan dunia pendidikan.

Pada konsepnya pengembangan wisata syariah bukanlah wisata istimewa karena wisatawan non-Muslim dapat menikmati pelayanan beretika syariah. Wisata halal bukan hanya keberadaan tempat wisata ziarah dan religi, melainkan tersedianya fasilitas pendukung, seperti restoran halal, hotel syariah serta lokasi shalat. Dalam wisata halal, produk maupun jasa serta tujuan wisata sama seperti wisata umumnya tetapi lebih ditekankan pada nilai etika syariah. Tetapi sampai saat ini, kearifan lokal dan budaya yang ada di ponorogo belum memiliki daya tarik bagi wisatawan. Mengapa wisata syariah penting di kembangkan di ponorogo?

Perkembangan wisata syariah memberikan dampak multidimensi. Salah satu dampak positifnya adalah penyerapan tenaga kerja dan pengentasan kemiskinan. Seperti yang kita ketahui bersama bahwa ponorogo merupakan kabupaten yang banyak mengirimkan TKI dan TKW ke luar negeri, pada tahun 2013 jumlah TKI dan TKW ponorogo berjumlah 4.488 orang (BPS, 2017). Sedangkan garis kemiskinan dan penduduk yang ada di kabupaten ponorogo tahun 2016 berjumlah 102.06 ribu jiwa yaitu sekitar $11,75 \%$ penduduk kabupaten ponorogo.

Sehingga di harapkan dengan adanya pengembangan wisata syariah ini maka jumlah penduduk miskin dan penduduk yang menjadi TKI atau TKW kabupaten ponorogo akan berkurang. Pengembangan wisata syariah merupakan upaya dalam memajukan, dan memperbaiki wilayah sehingga memberikan nilai tambah dan manfaat bagi penduduk setempat, terutama warga sekitar tempat wisata dan pemerintah wilayah. Menurut Kaiser \& Helber dalam Yoenti, menyebutkan bahwa perencanaan wisata syariah berdasarkan pengembangan pariwisata daerah yang mencakup pembangunan fisik objek, atraksi wisata yang akan di jual, pelayanan umum, angkutan wisata, akomodasi, restoran \& perencanaan promosi yang akan di lakukan (Oka, 2008).

Pengembangan bisnis wisata syariah di ponorogo ini semakin manarik, mengingat masyarakat ponorogo merupakan masyarakat yang pluralism. Dimana masyarakat ponorogo menganut berbagai macam budaya, agama dan aliran 
kepercayaan. Dari jumlah penduduk sebanyak 965.809 ribu jiwa di tahun 2017, yang beragama islam sebanyak 849.127 ribu jiwa, Kristen 3.864 ribu jiwa, Katolik 3.268 ribu jiwa, Hindu 92 ribu jiwa, Budha 271 ribu jiwa dan KH 15 ribu orang (BPS, 2017). Sedangkan aliran kepercayaan atau biasa di sebut sebagai Himpunan Penghayat Kepercayaan (HPK) di ponorogo terdapat 22 organisasi, diantaranya Purwo Ayu Mardi Utomo beranggotakan 11300 jiwa, Ilmu Sejati beranggotakan 6000 jiwa, Aliran kebatinan perjalanan beranggotakan 6400 jiwa, Sapto darmo beranggotakan 2300 jiwa, Pelajar kawruh jiwa beranggotakan 680 jiwa, Kautaman kasampurnan beranggotakan 600 jiwa, Paguyuban wirid sadar beranggotakan 500 jiwa (Rofiq, 2014).

Sehingga pengembangan wisata syariah di ponorogo yang bermasyarakat majemuk, diperlukan peran pemerintah setempat menjadi leading sector untuk menentukan perencanaan \& pembangunan wisata syariah daerah. Interprestasi aspek lingkungan internal \& eksternal kabupaten ponorogo, maka identifikasi, analisis dan penentuan pengembangan strategi wisata syariah dapat ditentukan. Sesuai konsep yang di kemukakan oleh Wheelen dan Hanger yaitu langkahlangkah di dalam pengembangan destinasi wisata syariah di mulai dari merekognisi faktor lingkungan internal \& eksternal setelah itu memformulasi, mengimplementasi serta mengevaluasi strategi (Wheelen, 2000). Clarke mengemukakan hal pertama yang harus di lakukan untuk strategi pengembangan pariwisata terutama wisata syariah adalah perencanaan pengembangan produk lokal, mencari peluang untuk ekspansi pasar dan menentukan preferensi jangka panjang bagi industri lokal (Godfrey, 2000). Pengembangan wisata syariah di mulai dari merencanakan \& memperbaikan produk lokal, dengan meningkatkan potensi wisata daerah melalui pengembangan potensi alam sebagai destinasi wisata syariah. Langkah selanjutnya adalah mengenali kekuatan, kelemahan, peluang dan ancaman, dengan menelaah faktor internal eksternal pada tempat wisata, sehingga dapat merumusan Strategy alternative yang digunakan untuk mengembangkan destinasi wisata syariah daerah.

Walaupun konsep syariah merupakan kultur mayoritas penduduk, namun perkembangan wisata halal di Indonesia sangat lambat. Tantangan pengembangan wisata halal antara lain (1) Terdapat anggapan bahwa wisata halal tidak memiliki prospek pasar yang besar, sehingga upaya untuk meningkatkan wisata syariah inikurang maksimal, (2) mayoritas masyarakat muslim, sehingga beranggapan semua sarana dan prasarana sudah halal, tanpa mau untukbelajar \& berinovasi, (3) belum adanya standar peraturan tentang hotel, spa, sauna, obyek wisata, biro perjalanan berdasarkan padafatwa DSN-MUI (Rasyid, 2017). Hal tersebut juga terjadi di kabupaten Ponorogo. Dari segi pariwisata ponorogo masih sangat kurang pengembangannya, terutama wisata alamnya. Selama ini ponorogo hanya di kenal 
dengan kesenian reognya, padahal masih banyak destinasi wisata yang ada di ponorogo yang perlu di kembangkan.

4 kategori obyek wisata Ponorogo, yaitu obyek wisata budaya, obyek wisata industri, obyek wisata alam dan obyek wisata religi (BPS, 2017). Segenap potensi obyek wisata tersebut tentunya dapat dikembangkan dalam bentuk bisnis wisata syariah. Diantaranya adalah:

Pertama, Obyek wisata budaya. Yang terkenal adalah Grebek suro dirayakan setiap tanggal 1 muharram, rangkaian acaranya kirab pusaka, festival reog nasional, larung risalah do'a di Telaga ngebel. Selain itu, terdapat taman rekreasi singo pitu, pentas wayang kulit dan reog bulan purnama.

Kedua, Obyek wisata industri. Sentra industry yang ada di ponorogo, diantaranya industry seng di desa Paju kecamatan Ponorogo, industry jenang di desa Josari kecamatan Jetis, industri kulit di desa Nambangrejo kecamatan Sukorejo serta industry holtikultura di kecamatan Pudak kabupaten Ponorogo.

Ketiga, Obyek wisata alam, adalah Telaga ngebel di kecamatan Ngebel, Taman wisata ngembak di kelurahan Ronowijayan, Air terjun pletuk di desa Njuruk kecamatan Sooko, Gunung bayangkaki di desa Temon kecamatan Sawoo, Air terjun juruk klenteng di desa Juruk kecamatan Sawo, Goa Lowo di kecamatan Sampung, Hutan wisata kucur di kecamatan Badegan, Air terjun Toyomerto di desa Pupus kecamatan Ngebel, Air terjun Setapak, di desa Banaran kecamatan Pulung.

Keempat, Obyek wisata religi, dua jenis objek wisata religi yaitu objek wisata ziarah dan obyek wisata agama. 2 objek wisata ziarah adalah makam bathara katong di desa Setono kecamatan Jenangan dan makam Gondoloyo di desa Tanjungsari kecamatan Jenangan. Patung Maria yang berada di Mata air sendang waluyo jati yang merupakan tempat ibadah penganut katolik terletak desa Klepu Kecamatan Sooko dan peninggalan Kyai Ageng Besari yang terkenal dengan masjid tegalsari yang beraksitektur Jawa dengan 36 tiang, serta kitab berusia 400 tahun yang di tulis Ronggo Warsito di Desa Tegalsari kecamatan Jetis.

Dari keempat objek wisata tersebut posisi wisata syariah dapat mencangkup semua objek wisata. Baik wisata budaya, wisata industri, wisata alam maupun wisata religi. Hal ini dikarenakan keempat objek tersebut merupakan objek wisata yang tidak menyimpang dari ketentuan dan norma-norma, sehingga objek wisata syariah dapat dikembangkan dengan berkolaborasi dengan keempat objek wisata tersebut.

Berdasarkan penjabaran tersebut ponorogo mempunyai potensi untuk pengembangan wisata syariah, sehingga penulis berharap dapat memberikan masukan yang signifikan tentang strategi pengembangan bisnis wisata syariah di wilayah Ponorogo, yang bertujuan untuk mengembangkan produk dan pelayanan yang berkualitas, bertahap serta seimbang, yang akan mengangkat potensi lokal 
daerah, yang akan berimplikasi pada pengembangan ekonomi masyarakat daerah terutama kabupaten Ponorogo.

\section{Wisata Syari'ah}

Muhammad Munir Caudry berargumen bahwa wisata syariah membentuk konsep baru pariwisata yang bukan wisata religi seperti umroh dan ibadah haji. Wisata syariah merupakan pariwisata yang melayani liburan, dengan menyesuaikan gaya liburan traveler muslim, termasuk di dalamnya hotel dengan prinsip syariah yang memisahkan kolam renang dan spa untuk pria dan wanita (Wuryasti, 2013).

Menurut Hery Sucipto dan Fitria Andayani, wisata syariah merupakan rekreasi yang tidak bertentangan dan menyalahi prinsip- prinsip ajaran Islam, sertasejak awal diniatkan untuk mengagumi kebesaran ciptaan Allah. serta memberi manfaat bagi kehidupan umat manusia dan lingkungan sekitar (Hery Sucipto, 2014).

Thohir Bawazir mendefinisikan wisata syariah sebagai perjalanan wisata yang prosesnya sejalan dengan nilai- nilai syariah Islam, dimulai dari niatnya \& selama dalam perjalanannya dapat melakukan ibadah dengan lancar, setelah sampai tidak mengarah ke hal- hal yang bertentangan dengan syariah, makan dan minum halalan thoyyibah, hingga kepulangannya pun dapat menambah rasa syukur kita kepada Allah (Bawazir, 2013).

\section{Perbedaan Wisata Konvensional, Wisata Religi dan Wisata Syariah}

\section{Wisata konvensional}

Wisata konvensional objeknya berupa alam, budaya, heritage dan kuliner. Wisata ini bertujuan untuk menghibur yang targetnya untuk menyentuh kesenangan wisatawan. Guide yang memandu wisatawan harus memahami dan menguasai informasi sehingga bisa menarik wisatawan ke obyek wisata. Fasilitas Ibadah pada wisata ini hanya senabagai pelengkap saja, kuliner yang ada di obyek wisata juga merupakan kuliner umum yang belum jelas halal dan haramnya. Relasi dengan masyarakat di lingkungan objek wisata merupakan relasi komplementer dan semata hanya mengejar keuntungan. Agenda perjalanan pada wisata ini juga mengabaikan waktu.

\section{Wisata religi}

Wisata religi objeknya berupa tempat ibadah dan peninggalan sejarah. Wisata ini bertujuan untuk meningkatkan spiritualitas yang targetnya untuk menenangkan 
jiwa dan mencari ketenangan batin wisatawan. Guide yang memandu wisatawan harus menguasai sejarah tokoh dan lokasi tempat wisata. Fasilitas Ibadah pada wisata ini hanya senabagai pelengkap saja, kuliner yang ada di obyek wisata juga merupakan kuliner umum yang belum jelas halal dan haramnya. Relasi dengan masyarakat di lingkungan objek wisata merupakan relasi komplementer dan semata hanya mengejar keuntungan. Agenda perjalanan pada wisata ini peduli perjalanan.

\section{Wisata syariah}

Wisata syariah objeknya berupa semua obyek pariwisata. Wisata ini bertujuan untuk meningkatkan spirit religiusitas dengan cara menghibur. Guide yang memandu wisatawan harus membuat wisatawan tertarik pada obyek sekaligus membangkitkan spirit religiusitas wisatawan. Fasilitas Ibadah pada wisata ini menjadi bagian yang menyatu dengan obyek wisata dan ritual ibadah menjadi paket hiburan wisata, kuliner yang ada di obyek wisata merupakan kuliner yang spesifik halalnya. Relasi dengan masyarakat di lingkungan objek wisata merupakan interaksi berdasarkan pada prinsip-prinsip syariah. Agenda perjalanan pada wisata ini sangat memperhatikan waktu.

\section{Pengembangan Wisata Syari'ah}

Perencanaan secara menyeluruh dan berkesinambungan merupakan hal yang penting di dalam pengembangan pariwisata, yang hasilnya bisa di manfaatkan oleh masyarakat dari sisi ekonomi, sosial dan budaya. Marpaung berpendapat bahwa mengembangkan infrastruktur \& fasilitas rekreasi akan memberikan keuntungan bagi wisatawan maupun penduduk lokal, sehingga masalah kemiskinan akan berkurang dan pelancong akan mempunyai pengalaman dan kebahagiaan saat berpariwisata (Sammeng, 2000).

Dalam kaitannya dengan strategi pengembangan wisata, Arif Yahya, selaku menteri pariwisata, mengemukakan beberapa resep peningkatan kunjungan wisata yang meliputi tiga aspek yakni atraksi, aksessibilitas dan amenitas (Muhammad, 2017). Sedangkan menurut Coper at all dalam Sunaryo, mengemukakan bahwa terdapat 5 unsur/ komponen dalam pengembangan obyek wisata, yaitu: (Objek dan Daya Tarik (Attraction), Aksesibilitas (Accessibilities), Amenitas (Amenitie), yang mencakup fasilitas penunjang maupun pendukung wisata, Fasilitas 
Pendukung (Ancillary Services), dan Kelembagaan (Institutions) (Sunaryo, 2013). Adapun penjelasannya sebagai berikut:

Pertama, objek dan Daya Tarik (Attraction), merupakan obyek pariwisata berbasis kekayaan alam, budaya ataupun buatan, contohnya event. Menurut Gun dalam Sedarmayanti,dkk, mengemukakan "the atraction represent the most important reason for travel to destination." Atraksi dapat berntuk pemanfaatan alam sebagai wahana atraksi dan atraksi yang memanfaatkan budaya sebagai pertunjukan seni atau apresiasi seni yang dikembangkan oleh masyarakat di suatu destinasi atau nilai tradisional yang merupakan tradisi yang diselenggarakan secara turun temurun yang memiliki nilai budaya tinggi dan dapat didukung wisatawan. Atraksi menjadi amat penting bagi perkembangan destinasi, Chuk Y Gee 'The attraction and attributes of a destination are important with respect to sight seeing, recreation, shopping, entertainment, and other fromof pleasure travel" (Sedarmayanti, 2018).

Kedua, kemudahan akses (Accessibilities), merupakan pengembangan pariwisata dengan melihat sarana transportasi, misalkan adanya terminal, stasiun, bandara atau pelabuhan. Adapun pengertian aksesibilitas menurut Sedarmayanti $\mathrm{dkk}$, adalah semua jenis sarana dan prasarana transportasi yang mendukung pergerakan wisatawan dari suatu tempat ke tempat lain dan mendukung perjalanan wisatawan dari tempat asal menuju ke suatu destinasi dan kembali ke tempat asal (Sedarmayanti, 2018). Sedangkan menurur French dalam Bambang Sunaryo, ke faktor- faktor yang penting dan terkait dengan aspek aksesibilitas wisata ini meliputi: "road signage, access to tourist attraction, regional airport, and ground transport, time taken to reach the destination, the cost of traveling to the destination, and the frequency of transport to the destination.” Tidak hanya menyangkut kemudahan transportasi bagi wisatawan untuk mencapai sebuah tempat wisata, waktu yang dibutuhkan dan tanda penunjuk arah menuju lokasi wisata juga termasuk aksessibilitas (Sunaryo, 2013).

Ketiga, amenitas (Amenitie), merupakan fasilitas penunjang maupun pendukung wisata. Fasilitas tersebut diantaranya: akomodasi, rumah makan (food and beverage), retail, toko cinderamata, biro perjalanan, retail, pusat informasi wisata, fasilitas penukaran uang (money changer) serta fasilitas-fasilitas lain untuk menunjang kenyamanan. Menurut Arif Yahya dalam Muhammad Djakfar, aspek ini tidak hanya berkaitan dengan fasilitas yang memberi atmosfer kenyamanan, 
tetapi juga berkaitan dengan pelayanan yang memadai. Aspek amenitas ini juga merupakan kekuatan daya tarik sebuah destinasi wisata yang seharusnya mendapat perhatian para pengelola secara berkesinambungan. Hal ini dikarenakan pesona objek wisata tidak akan mempunyai nilai yang berarti tanpa diimbangi dengan ketercukupan fasilitas yang dibutuhkan dan disertai pula dengan pelayanan yang prima(Muhammad, 2017).

Keempat, fasilitas Pendukung (Ancillary Services), adalah ketersediaan fasilitas pendukung yang digunakan oleh wisatawan. Fasilitas pendukung tersebut meliputi bank, telekomunikasi, pos, rumah sakit dan fasilitas lainnya. Kelima, kelembagaan (Institutions), yaitu keberadaan serta peran dari masing-masing unsur yang mendukung terlaksananya kegiatan pariwisata, termasuk masyarakat setempat sebagai tuan rumah (host).

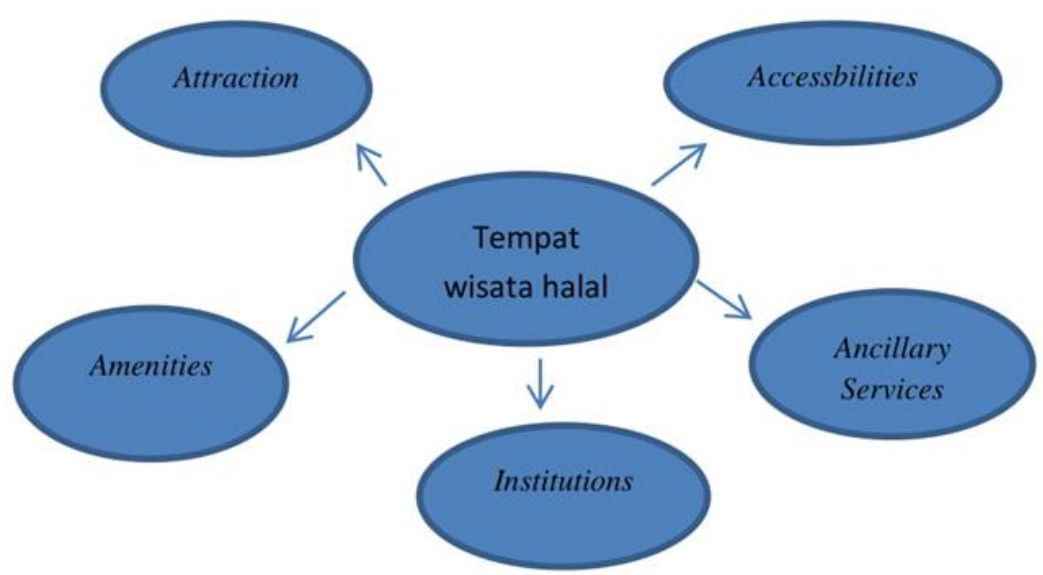

\section{Gambar 1. Ilustrasi kontruksi sistem pengembangan tempat wisata syariah}

Untuk tercapainya pengembangan dan pengelolaan destinasi pariwisata yang berdaya guna dan berhasil guna serta mendukung pembangunan kepariwisataan, perlu pengelolaan destinasi pariwisata yang didukung oleh seluruh stakeholder kepariwisataan, baik yang terkait langsung maupun tidak langsung dengan pengembangan dan pengelolaan sebuah destinasi pariwisata. Salah satu bentuk pengelolaan destinasi pariwisata adalah Destination Management Organization yang selanjutnya disingkat DMO. DMO berfungsi untuk mengelola dan 
mengkoordinasikan elemen - elemen sebuah destinasi (daya tarik wisata, SDM, citra, pemasaran, atraksi wisata, harga, lingkungan yang berkelanjutan serta sumber- sumber daya destinasi, fasilitas umum). DMO menjadi sebuah perspektif yang hendak memberikan ruang partisipasi bagi semua pihak agar terlibat dalam pengembangan dan pengelolaan sebuah destinasi pariwisata (Muhammad, 2017).

\section{Manajemen Strategi}

Tujuan dari manajemen strategis yaitu mengeksploitasi dan menciptakan berbagai peluang baru yang berbeda untuk masa mendatang dan perencanaan jangka panjang serta mencoba untuk mengoptimalkan trend-trend sekarang untuk masa yang akan datang. Manajemen strategis meliputi pengamatan lingkungan, perusahaan strategi, dan evaluasi serta pengendalian. Manajemen strategis menekankan pada pengamatan dan evaluasi peluang dan ancaman lingkungan dengan melihat kekuatan dan kelemahan perusahaan. Sehingga dapat dikatakan bahwa manajemen strategis merupakan cara untuk mengelola semua sumberdaya guna mengembangkan keunggulan kompetitif jangka panjang. Salah satu bentuk dari analisis SWOT adalah analisis lingkungan.

Analisis lingkungan ini meliputi kegiatan memonitor, evaluasi, dan mengumpulkan informasi dari lingkungan eksternal dan internal perusahaan. Tujuan dari kegiatan tersebut yaitu untuk mengidentifikasi faktor strategis, elemen eksternal dan internal akan memutuskan strategi dimasa yang akan datang bagi perusahaan (Muhammad, 2017). Melakukan analisis lingkungan ini dimerlukan suatu alat analisis yang dinamakan analisis SWOT. SWOT merupakan akronim yang digunakan untuk mendeskripsikan strengths (kekuatan), weaknesses (kelemahan), opportunities (peluang), dan threaths (ancaman) yang merupakan faktor strategis bagi perusahaan spesifik (Muhammad, 2017).

Analisis SWOT adalah teknik historis yang terkenal dimana para manajer menciptakan gambaran umum secara cepat mengenai situasi strategis perusahaan. Analisis ini didasarkan pada asumsi bahwa strategi yang efektif diturunkan dari "kesesuaian" yang baik antara sumber daya internal perusahaan (kekuatan dan kelemahan) dengan situasi eksternalnya (peluang dan ancaman). Kesesuaian yang baik akan memaksimalkan kekuatan dan peluang perusahaan serta meminimalkan kelemahan dan ancaman. Jika diterapkan secara akurat, asumsi 
sederhana ini memiliki implikasi yang bagus dan mendalam bagi desain dari strategi yang berhasil (John, 2008).

Berdasarkan pembahasan mengenai analisis SWOT, maka peluang- peluang dan ancaman-ancaman dari hasil analisis eksternal, bersama dengan kekuatankekuatan dan kelemahan-kelemahan perusahaan dari hasil analisis internal akan menjadi masukan dalam menyusun analisis SWOT. Setelah dilakukan analisis SWOT yang memetakan analisis lingkungan eksternal dan internal perusahaan, maka perusahaan tentunya memikirkan bagaimana perusahaan menggunakan analisis SWOT dalam menuangkan strategi yang akan dilakukan. Berikut tabel analisis SWOT pengembangan wisata syariah di ponorogo:

\begin{tabular}{|c|c|c|}
\hline \multirow{2}{*}{$\begin{array}{l}\text { Faktor } \\
\text { Internal }\end{array}$} & Kekuatan (S) & Kelemahan (W) \\
\hline & $\begin{array}{l}\text { 1. Ponorogo mempunyai potensi untuk } \\
\text { menjadi salah satu destinasi wisata } \\
\text { syari'ah di indonesia, hal ini karena } \\
\text { banyak wisata religi dan pondok } \\
\text { poesantren yang ada di ponorogo, serta } \\
\text { wisata alam yang belum di kembangkan. } \\
\text { 2. Walaupun belum banyak pengetahuan } \\
\text { masyarakat terhadap sertifikat halal, } \\
\text { tetapi produk halal sudah menjadi } \\
\text { kewajiban dan kehidupan sehari-hari } \\
\text { masyarakat ponorogo. } \\
\text { 3radisi grebeg reog yang diadakan setiap } \\
\text { tahunnya di Ponorogo, merupakan even } \\
\text { budaya internasional yang bisa di } \\
\text { kembangkan dan di kemas kedalam } \\
\text { even-even yang bersyariah, misalkan } \\
\text { melarang penggunaan minuman keras di } \\
\text { even tersebut. }\end{array}$ & $\begin{array}{l}\text { 1. Sebagian besar pelaku industri } \\
\text { belum menyantumkan sertifikasi } \\
\text { halal. } \\
\text { 2. Belum siapkan ponorogo dalam } \\
\text { pengembangan wisata halal, hal } \\
\text { ini karena SDM yang terbatas, di } \\
\text { samping itu pembangunannya } \\
\text { memerlukan biaya yang besar. } \\
\text { 3. Masyarakat ponorogo tidak } \\
\text { memperdulikan dalam } \\
\text { pengembangan wisata syari'ah, } \\
\text { sehingga destinasi alam di } \\
\text { ponorogo banyak yang rusak dan } \\
\text { tidak terawat. } \\
\text { Minimnya anggaran daerah di } \\
\text { dalam pengembangan wisata } \\
\text { syari'ah di ponorogo, terutama di } \\
\text { pengembangan sektor alamya. }\end{array}$ \\
\hline
\end{tabular}

\section{Gambar 2. Analisis Faktor Internal}

Dalam penyusunan strategi, perusahaan tidak selalu harus mengejar semua peluang yang ada. Tetapi, perusahaan dapat membangun suatu keuntungan kompetitif dengan mencocokkan kekuatannya dengan peluang masa depan yang akan dikejar. Untuk dapat membangun strategi yang mempertimbangkan hasil dari analisis SWOT, dibangunlah TOWS Matriks. TOWS Matriks (TOWS hanya kebalikan atau kata lain dalam ungkapan SWOT) mengilustrasikan bagaimana peluang dan ancaman pada lingkungan eksternal dapat dipadukan 
dengan kekuatan dan kelemahan dari perusahaan, sehingga hasil yang diperoleh dapat digambarkan melalui empat set alternatif strategi (Hunger, 2015)

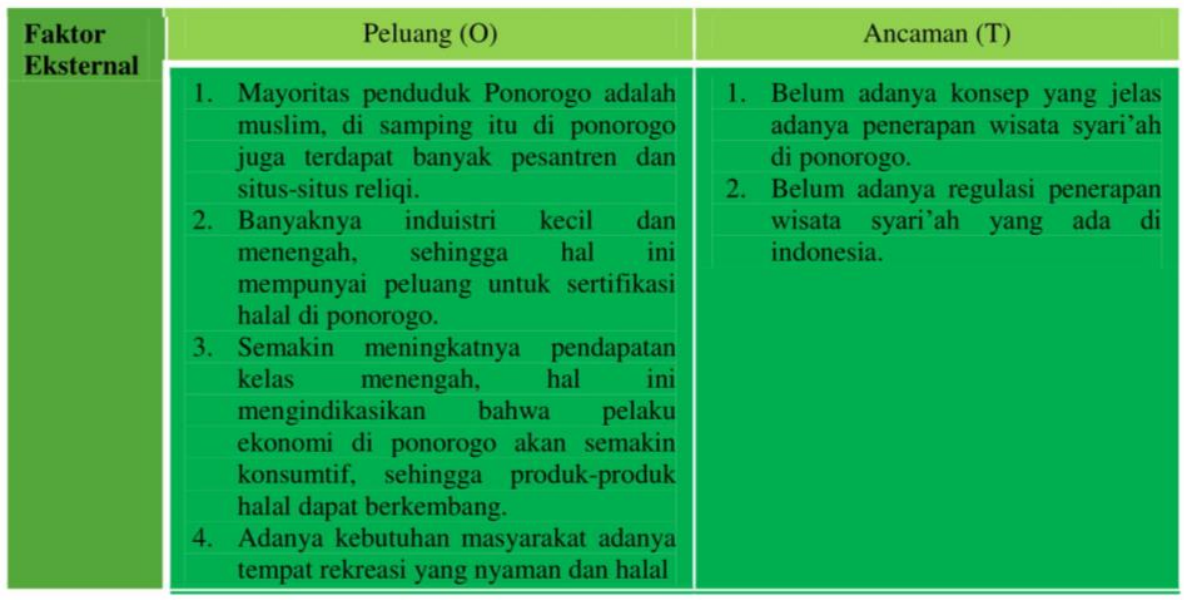

\section{Gambar 3. Analisis Faktor Eksternal}

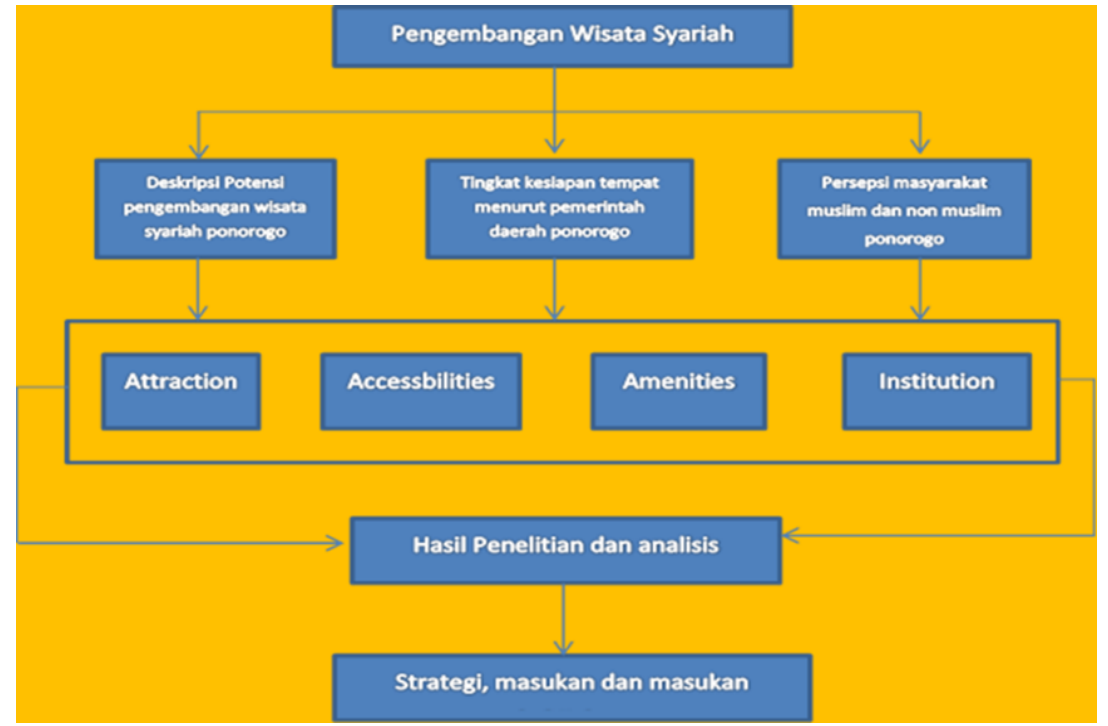

Gambar 4. Skema proses Strategi pengembangan wisata syari'ah di ponorogo 


\section{Potensi Market Wisatawan di Ponorogo}

Jumlah kunjungan wisatawan ke ponorogo dalam waktu 3 ntahun terakhir terius mengalami peningkatan. Dalam Statistik ponorogo menunjukkan di pertengahan tahun 2019 ini jumlah wisatan ponorogo mengalami kenaikan, yaitu 500 ribu wisatan di tahun 2019. Meningkat dua kali libat di bandingkan tiga tahun terakhir yeti 100 ribu wisatawan. Data pusat statistic menunjukkan kemaikan jumlah wisatawan yang berkunjung di ponorogo, yeti tahun 2016 sebanyak 100 ribu orang, 2017 sebanyak 150 ribu orang, tahun 2018 sebanyak 300 orang dan akhir tahun 2019 ini sudah menunjukkan jumlah 625 ribu orang. Kenaikan jumlah wisatawan ini tidak lepas dari pengembangan destinasi wisata rintisan dan kegiatan seni budaya yang terus di galakkan.

\section{Dampak Wisata Terhadap PAD Kabupaten Ponorogo}

Geliat pariwisata di ponorogo di samping menaikkan jumlah destinasi alam di ponorogo juga berdampak pada kenaikan Pendapatan Asli Daerah (PAD) kabupaten ponorogo. Pada tahun 2018 ini PAD Ponorogo mengalami kebaikan 200\% dari tahun sebelumnya, dan melebihi target yang telah di tentukan. Pada tahun 2018 ini PAD ponorogo dari sector pariwisata sebesar RP. 1,45 Milyar, yang mana target di tahun itu hanya 845 juta rupiah. Penyumbang terbesar Pendapatan daerah dari sector wisata ini adalah kecamatan ngebel yeti telaga ngebel. Dan kecamatan Sooko dan Pudak yaitu Mloko sewu dan pemandian air hangat Tirto Usodo.

\section{Pengembangan Wisata Syari’ah di Ponorogo}

\section{Attraction, Pengembangan Wisata di lihat dari Kekayaan Alamnya}

Kabupaten Ponorogo adalah sebuah kabupaten di provinsi Jawa timur, yang terletak di koordinat $111^{\circ} 17^{\prime}$ - 111 ${ }^{\circ} 52^{\prime}$ BT dan 7०49’ - 8॰20’ LS dengan ketinggian antara 92 sampai dengan 2.563 meter diatas permukaan laut dan memiliki luas wilayah 1.371,78 km2. Menurut Dinas Pariwisata kabupaten ponorogo, terdapat banyak potensi wisata dan budaya yang ada di kabupaten ponorogo, yaitu: 1) gua, berada di kecamatan sampung, bungkal dan sawoo; 2) makam religi, berada di kecamatan slahung, pulung, jetis, bagedan dan jenangan; 3) telaga, berada di kecamatan ngebel; 4) taman/hutan wisata, berada di kecamatan ponorogo, ngebel, 
slahung, badegan; 5) mata air/sumber air, berada di kecamatan bungkal, Sukoo, Sambit dan Siman; 6) air terjun, berada di Sawoo, suko dan Balong; 7) gunung, berada di Slahung, Sawoo.

Accessbilities, yang mencakup dukungan sistem transportasi.

Kabupaten ponorogo terletak di $27 \mathrm{~km}$ sebelah selatan kota madiun dan berada di jalur Madiun-Pacitan, serta jalur Madiun Trenggalek. Sehingga untuk saat ini ponorogo hanya bisa di tempuh melalui jalur darat. Baik menggunakan fasilitas bus umum, maupun kendaraan pribadi, maupun kendaraan tradisional. Kendaraan tradisional yang ada di ponorogo bernama dokar. Dokar biasa di gunakan di daerah pedesaan, yang biasa di gunakan untuk mengangkut pedagang maupun sayur untuk menuju pasar tradisional. Bus Dalam kota, digunakan untuk menghubungkan pusat kabupaten dengan kecamatan-kecamatan di pinggiran, bus kota ini merupakan bus mini dengan tarif yang sangat ekonomis. Angkodes, angkutan sejenis angkot yang merupakan transportasi umum Bus antar kota, yang berpusat di terminal seloaji menghubungkan kota-kota yang ada di jawa timur.

\section{Amenities}

Mencakup fasilitas penunjang maupun pendukung wisata diantaranya: akomodasi, rumah makan (food and beverage), toko cendramata. Ponorogo merupakan salah satu daerah tujuan wisata di wilayah Madiun Raya. Keberadaan hotel dan penginapan sangat penting dalam menunjang kegiatan pariwisata di kota reog. Jumlah hotel yang ada di wilayah ponorogo sebanyak 67 hotel baik kelas berbintang maupun melati, dari 67 hotel tersebut 33 hotel berada di wilayah telaga ngebel, hal ini karena ngebel merupakan icon wisata ponorogo.

Dari 67 hotel tersebut ada 13 hotel berbintang dua atau satu, yang lainnya adalah kelas melati. Namun, $80 \%$ hotel yang ada di ponorogo belum memiliki hotel syari'ah, walaupun banyak yang menerapkan prinsip syari'ah. Untuk rumah makan ponorogo memiliki 57 tempat kuliner makan di ponorogo, baik restoran dengan harga mahal maupun harga murah. Untuk sertifikasi produk halal, BPPOM MPU perlu sosialisasi adanya sertifikat halal . Toko cenderamata juga banyak tersebar di wilayah ponorogo, terutama jajanan khas ponorogo yeti dodol dan sate ayam, begitu juga toko penjual pernak pernik reog banyak tersebar di wilayang ponorogo. 


\section{Ancillary Services}

Mencakup seperti rumah sakit, bank, pos, telekomunikasi dan lainnya. Untuk melayanan kesehatan dan perputaran uang di ponorogo sudah sangat bagus, dalam pelayanan kesehatan terdapat 6 rumah sakit besar bertaraf nasional, yang berada di pusat kota Ponorogo, sedangkan untuk pukesmas dan klinik kesehatan sudah tersebar di setiap desa dan kelurahan di seluruh wilayah ponorogo. Jadi untuk pelayanan kesehatan, sudah menjangkau desa-desa di seluruh kabupaten ponorogo.

Sedangkan untuk perbankan juga sudah tersebar di setiap akses atau jantung perekonomian di setiap kecamatan yang ada di wilayang kabupaten ponorogo, pelayanan ATM pun juga berada di setiap jantung perekonomian setiap kecamatan yang ada di wilayah ponorogo. Sedangkan untuk sarana telekonomikasi, seluruh wilayah ponorogo bisa di jangkau semua jaringan telekonomikasi yang ada.

\section{Kesimpulan}

Pengembangan wisata syari'ah di ponorogo apabila di lihat dari Persepsi masyarakat ponorogo baik masyarakat muslim, masyarakat non muslim maupun pemerintah daerah ponorogo, di lihat dari destinasi alam ponorogo yang mengalami peningkatan, assebilitas, akomodasi dan dukungan dari pemerintah daerah maka pemerintah ponorogo siap dengan adanya pengembangan wisata syariah di ponorogo, hal ini di dukung oleh ketersediaan makanan halal, jumlah hotel dan penginapan serta adanya kerjasama dari stakeholder. Dari unsur ketersediaan makanan halal, ponorogo siap menyajikan makanan halal hal ini karena jumlah penduduk muslim, jumlah pesantren yang ada di ponorogo, serta budaya"gak neko-neko" maka dari unsur makanan maka wilayah ponorogo siap menyajikan makanan halal di kabupaten ponorogo. Tetapi masih adanya kendala yaitu sebagian besar UMKM Makanan di ponorogo belum tahu adanya sertifikat halal, sehingga ini merupakan tantangan dari berbagai pihak terutama pemerintah daerah untuk lebih bekerja keras dalam mensosialsisasi sertifikat halal dalam makanan. Dari unsur jumlah penginapan dan hotel yang ada di ponorogo, serta persepsi masyarakat baik muslim maupun non muslim, di simpulkan bahwa ponorogo dari sisi Akomodasi hotel dan penginapan di nilai belum siap, menyanangkan hotel syari'ah hal ini karena dari dari 67 hotel yang ada di 
ponorogo, $80 \%$ masih hotel melati yang sifatnya "remah-remang", sehingga belum mempunyai sertifikat halal. Sehingga perlu adanya kerjasama di semua unsur masyarakat, baik hal ini masyarakat ponorogo sendiri sebagai obyek pengembangan wisata halal, ulama, akademisi dan pemerintah agar pariwisata ponorogo dapat terwujub, hal ini memerlukan waktu yang cukup lama, mengingat bahwa saat ini ponorogo masih dalam taraf pengembangan destinasi wisata (memperbanyak destinasi wisata).

\section{DAFTAR PUSTAKA}

A, Yoeti Oka. (1982). Pengantar Ilmu Pariwisata. Bandung: Angkasa.

B, P.J. (2008). Manajemen Strategis. Jakarta: Salemba Empat.

Bappennas. (2015). Masterplan Arsitektur Keuangan Syari'ah Indonesia (AKSI) .Jakarta.

BAPPENNAS. (2018). Masterplan Ekonomi Syari'ah Indonesia 2019 - 2024. Jakarta: BAPPENNAS.

Bawazir, T. (2013). Panduan Praktis Wisata Syariah. Jakarta: Pustaka Al-Kausar. BPS. (2017). Badan Pusat Statistik Kabupaten Ponorogo. Ponorogo: BPS.

Dini, Andriani, et al. (2015) Laporan awal kajian pengembangan wisata syariah. Jakarta: Kementrian Pariwisata RI.

Estimasi World Population Prospects,UN.2017.

Fred R, David. (2006). Manajemen Strategi. Ed ke-10. Jakarta: Salemba Empat.

Godfrey, k. a. (2000). A practical Approach to planning and marketing. London: Continuum.

Hamzah, Maulana. M., dan Yudiana, Yudi. (2015). Analisis Komparatif Potensi Industri Halal dalam Wisata Syariah dengan Konvensional.Republika.

Hery Sucipto, F. A. (2014). Karakter, potensi, prospek dan tantangan wisata syari'ah .Jakarta: Group Grafindo Khasanah Ilmu.

Hunger, W. a. (2015). Manajemen Strategis. Yogyakarta: Andi Offset.

Irwanto. (2006). Focused Group Discussion (FGD) : Sebuah Pengantar Praktis. Jakarta: Yayasan Obor Indonesia.

John, R. R. (2008). manajemen Strategis. Jakarta: Salemba Empat.

Kilinç, Akyol. (2014). Internet and Halal Tourism Marketing. International Periodical For The Languages, Literature and History of Turkish or Turkic Volume 9/8 Ankara-Turkey. 
Masterplan Arsitektur Keuangan Syari'ah Indonesia

Muhammad, D. (2017). Pariwisata halal perspektif multimedia. Malang: UIN Maliki Press.

Murdaningsih, Dwi dan Pratiwi, Fuji. (2015). Wisata Halal Indonesia Kalah Dibanding Malaysia dan Thailand. Republika.

Nasional, K. P. (2018). Masterplan Ekonomi Syari'ah di Indonesia 2019 - 2014. Jakarta: Kementrian Perencanaan Pembangunan Nasional.

Nations, U. (2017). World Population Prospects. Multimedia Library.

OJK. (Mei 2019). Aset industri keuangan syari'ah di Indonesia. Jakarta: Otoritas Jasa Keuangan (OJK).

Oka, Y. (2008). Perencanaan dan pengembangan pariwisata. Jakarta: PT. Pradnya paramita.

Priyadi,Unggul. (2016). Pariwisata Syari'ah: Prospek dan pengembangannya. UPP STIM YKPM.

Rasyid, A. (2017, november 18). Peluang dan tantangan wisata halal di indonesia. Binus University, pp. 1-2.

Rofiq, A. C. (2014). Kebijakan pemerintah terkait hak sipil aliran penghayat kepercayaan dan implikasinya terhadap perkembangan penghayat kepercayaan di ponorogo. Kodifikasia Vo.8,No.1.

S, Pendit Nyoman. (2006). Ilmu Pariwisata Sebuah Pengantar Perdana. Jakarta: Pradnya Paramitha.

Sammeng, A. M. (2000). Cakrawala Pariwisata. Jakarta.

Sudarmayanti, d. (2013). Pembangunan dan pengembangan pariwisata . Bandung: PT. Refika Aditama.

Sugiyono. (2012). Metode penelitian kuantitatif, kualitatif dan RD. Bandung. Alfabeta.

Sunaryo, B. (2013). Kebijakan pembangunan destinasi pariwisata, konsep dan aplikasinya di Indonesia. Yogyakarta.

Taufiq, Amir M. (2011). Manajemen Strategik Konsep dan Aplikasi. Jakarta : PT Raja grafindo Persada.

Undang-Undang tahun 2009 tentang Kepariwisataan.

Wheelen, T. a. (2000). Strategic management and business policy. Addisonwesley.

Wuryasti, F. (2013). Wisata halal konsep baru kegiatan wisata di indonesia. http://travel.detik.com. 